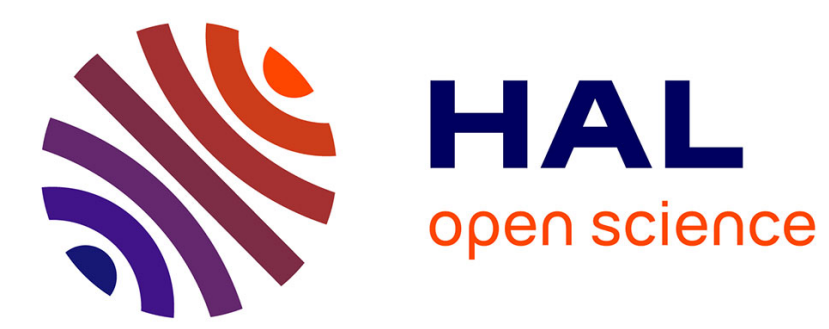

\title{
Semiconducting properties of Ge-doped BaSnO3 ceramic
}

Roberto Köferstein, Fahrettin Yakuphanoglu

\section{To cite this version:}

Roberto Köferstein, Fahrettin Yakuphanoglu. Semiconducting properties of Ge-doped BaSnO3 ceramic. Journal of Alloys and Compounds, 2010, 506 (2), pp.678-682. 10.1016/j.jallcom.2010.07.041 . hal-02005034

\section{HAL Id: hal-02005034 \\ https://hal.science/hal-02005034}

Submitted on 3 Feb 2019

HAL is a multi-disciplinary open access archive for the deposit and dissemination of scientific research documents, whether they are published or not. The documents may come from teaching and research institutions in France or abroad, or from public or private research centers.
L'archive ouverte pluridisciplinaire $\mathbf{H A L}$, est destinée au dépôt et à la diffusion de documents scientifiques de niveau recherche, publiés ou non, émanant des établissements d'enseignement et de recherche français ou étrangers, des laboratoires publics ou privés. 


\title{
Semiconducting properties of Ge-doped $\mathrm{BaSnO}_{3}$ ceramic
}

\author{
Roberto Köferstein, Fahrettin Yakuphanoglu \\ Journal of Alloys and Compounds 506 (2010) 678-682 \\ doi:10.1016/j.jallcom.2010.07.041
}

\begin{abstract}
The electrical and optical properties of Ge-doped $\mathrm{BaSnO}_{3}$ ceramics sintered at various temperatures have been investigated to determine their semiconductor behavior. The electrical conductivity of Ge-doped $\mathrm{BaSnO}_{3}$ samples increases with increase in temperature, confirming that the samples exhibit a semiconductor behavior. A maximum conductivity value of $6.31 \times 10^{-9} \mathrm{~S} / \mathrm{cm}$ was observed for the sample sintered at $1200{ }^{\circ} \mathrm{C}$. The optical band gaps of the Ge-doped $\mathrm{BaSnO}_{3}$ samples were determined by means of reflectance spectra. The variation of optical band gap with temperature was analyzed using $E_{\mathrm{g}}(T)=E_{\mathrm{go}}+\beta T$ relation. The rate of change of the band gap $\beta$ of $\mathrm{BaSn}_{0.99} \mathrm{Ge}_{0.01} \mathrm{O}_{3}$ was found to be $7.6 \times 10^{-4}\left(\mathrm{eV} /{ }^{\circ} \mathrm{C}\right)$. A minimum optical band gap value of $2.95 \mathrm{eV}$ was observed for the sample sintered at $1400{ }^{\circ} \mathrm{C}$. It is evaluated that $\mathrm{BaSn}_{0.99} \mathrm{Ge}_{0.01} \mathrm{O}_{3}$ is a wide band gap semiconductor and its semiconducting properties change with sintering temperature.
\end{abstract}

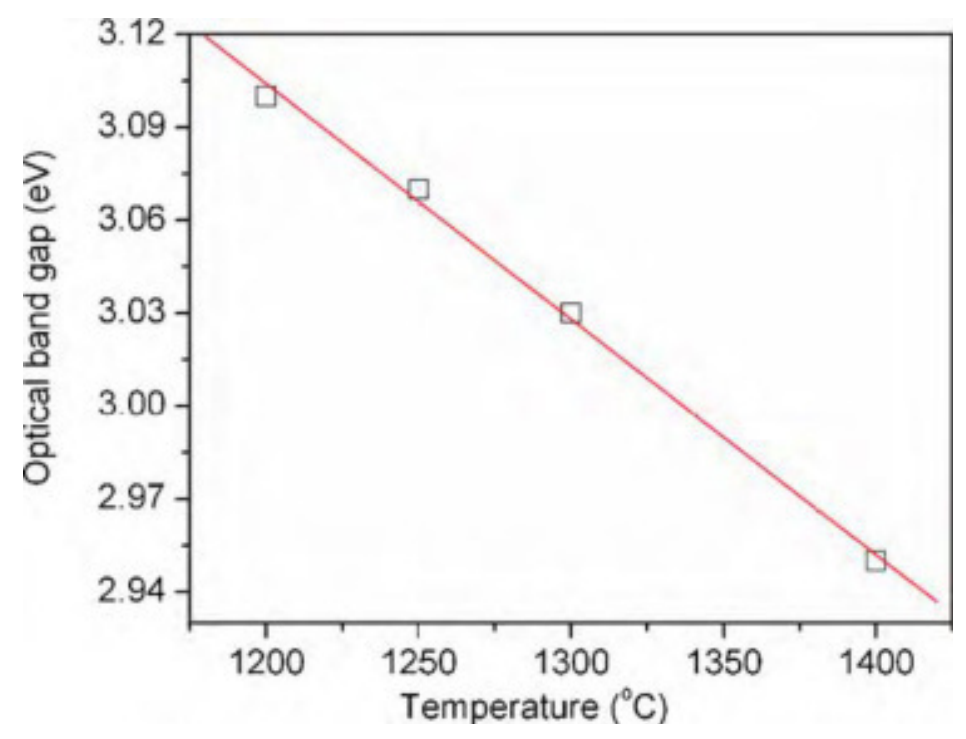




\title{
Semiconducting properties of Ge-doped $\mathrm{BaSnO}_{3}$ ceramic
}

\author{
Roberto Köferstein ${ }^{\mathrm{a}}$, Fahrettin Yakuphanoglu ${ }^{\mathrm{b}, *}$ \\ anstitut für Chemie, Anorganische Chemie, Martin-Luther-Universität Halle-Wittenberg, Kurt-Mothes Strasse 2, D-06120 Halle, Germany \\ ${ }^{b}$ Physics Department, Faculty of Science, Firat University, 23119 Elazığ, Turkey
}

\begin{abstract}
A B S T R A C T
The electrical and optical properties of Ge-doped $\mathrm{BaSnO}_{3}$ ceramics sintered at various temperatures have been investigated to determine their semiconductor behavior. The electrical conductivity of Gedoped $\mathrm{BaSnO}_{3}$ samples increases with increase in temperature, confirming that the samples exhibit a semiconductor behavior. A maximum conductivity value of $6.31 \times 10^{-9} \mathrm{~S} / \mathrm{cm}$ was observed for the sample sintered at $1200^{\circ} \mathrm{C}$. The optical band gaps of the $\mathrm{Ge}$-doped $\mathrm{BaSnO}_{3}$ samples were determined by means of reflectance spectra. The variation of optical band gap with temperature was analyzed using $E_{g}(T)=E_{g 0}+\beta T$ relation. The rate of change of the band gap $\beta$ of $\mathrm{BaSn}_{0.99} \mathrm{Ge}_{0.01} \mathrm{O}_{3}$ was found to be $7.6 \times 10^{-4}(\mathrm{eV} / \mathrm{C})$. A minimum optical band gap value of $2.95 \mathrm{eV}$ was observed for the sample sintered at $1400^{\circ} \mathrm{C}$. It is evaluated that $\mathrm{BaSn}_{0.99} \mathrm{Ge}_{0.01} \mathrm{O}_{3}$ is a wide band gap semiconductor and its semiconducting properties change with sintering temperature.
\end{abstract}

\section{Introduction}

Pure and doped barium stannate as well as its solid solutions (e.g. $\mathrm{BaTi}_{1-x} \mathrm{Sn}_{x} \mathrm{O}_{3}$ ) have found important applications in materials science and technology due to their dielectric properties, semiconducting behaviors and high thermal stability. Because of these characteristic properties, $\mathrm{BaSnO}_{3}$ based ceramics are becoming more and more important in material technology. It can be used to prepare thermally stable capacitors and to fabricate ceramic boundary layer capacitors [1-8]. Moreover, barium stannate can be also used as a functional material for semiconductor gas sensors [9-15] and photocatalytic applications [16-18]. $\mathrm{BaSnO}_{3}$ crystallises in the perovskite structure and has a band gap of $3.4 \mathrm{eV}$ [19]. It has been observed that an isovalent partial replacement of $\mathrm{Sn}^{4+}$ in $\mathrm{BaSnO}_{3}$ by other cations causes a modification in its electrical properties [5,20-22]. In general, compacts on the basis of $\mathrm{BaSnO}_{3}$ reveal only a moderate densification behavior $[2,23-26]$. Therefore, such ceramic bodies need high sintering temperatures or very long soaking times $[7,27,19]$. The addition of additives can significantly reduce the sintering temperature due to an improvement of the densification behavior. Wang et al. [28] used $\mathrm{SiO}_{2}$ as a sintering aid for $\mathrm{BaSnO}_{3}$ ceramics. Sintering additives can influence not only the sintering temperature but also the (di-)electric properties of the final ceramics [29]. Kumar and Choudhary [22] sintered $\mathrm{BaSnO}_{3}$ at $1200{ }^{\circ} \mathrm{C}$ adding $\mathrm{BaSiO}_{3}$. They found the formation of solid solutions

\footnotetext{
- Corresponding author. Tel.: +90 $424237000 \times 3621$; fax: +90 4242330062. E-mail addresses: fyhanoglu@firat.edu.tr, fyhan@hotmail.com (F. Yakuphanoglu).
}

of the type $\mathrm{BaSn}_{1-x} \mathrm{Si}_{x} \mathrm{O}_{3}(x=0-0.15)$. The $\mathrm{BaSn}_{1-x} \mathrm{Si}_{x} \mathrm{O}_{3}$ samples show NTCR (negative temperature coefficient of resistance) behavior and a better electrical conduction at elevated temperature than pure $\mathrm{BaSnO}_{3}$ ceramic bodies. $\mathrm{BaGeO}_{3}$ can be also used as a sintering aid to drastically reduce the sintering temperature as reported for $\mathrm{BaTiO}_{3}$-based ceramics [30-32]. Recently, Köferstein et al. [33] sintered $\mathrm{BaSnO}_{3}$ ceramics at very low temperatures adding $\mathrm{BaGeO}_{3}$ and they found a partial solid solubility of $\mathrm{BaGeO}_{3}$ in $\mathrm{BaSnO}_{3}$.

Here we present the results of our investigations on the electrical and optical properties of Ge-doped $\mathrm{BaSnO}_{3}$ ceramics to determine their semiconducting properties.

\section{Experimental details}

The preparation procedure is described elsewhere [33]. Briefly, a powder with the composition of $\mathrm{BaSn}_{0.99} \mathrm{Ge}_{0.01} \mathrm{O}_{3}$ was prepared via a conventional mixed-oxide method. Equivalent amounts of $\mathrm{BaCO}_{3}$ (Sabed VL 600, 99.9\%, Solvay), $\mathrm{SnO}_{2}$ ( $\geq 99.0 \%$, Merck) and $\mathrm{GeO}_{2}$ (99.999\%, Acros Organics) were milled in a PVC container for $24 \mathrm{~h}$ using $\mathrm{ZrO}_{2}$-balls and propan-2-ol ( $\left.m_{\text {powder }}: m_{\text {balls }}: m_{\text {Propan-2-ol }}=1: 1: 4\right)$. After filtering and drying the mixture was calcined in static air (heating rate $10 \mathrm{~K} / \mathrm{min}$ ) for $2 \mathrm{~h}$ at $1150^{\circ} \mathrm{C}$ to obtain a powder with a specific surface area of $3.9 \mathrm{~m}^{2} / \mathrm{g}$. Then the calcined powder was milled with $\mathrm{ZrO}_{2}$-balls and propan2 -ol in a PVC container for $2 \mathrm{~h}\left(m_{\text {powder }}: m_{\text {balls }}=1: 4\right)$. After filtering and drying the powder was mixed with 5 mass\% of a saturated aqueous solution of polyvinyl alcohol (PVA) as a pressing aid. Then the powder was pressed to pellets with a green density of about $3.5 \mathrm{~g} / \mathrm{cm}^{3}$. The pellets were sintered in static air for $1 \mathrm{~h}$ at 1200 , 1250,1300 and $1400^{\circ} \mathrm{C}$ (heating rate $10 \mathrm{~K} / \mathrm{min}$ ). The theoretical 
bulk density of the ceramic bodies was calculated as $7.22 \mathrm{~g} / \mathrm{cm}^{3}$ [34].

X-ray powder diffraction (XRD) patterns were recorded by a STOE STADI MP diffractometer at $20^{\circ} \mathrm{C}$ using CoK $\alpha_{1}$ radiation. The specific surface area was determined using nitrogen three-point BET (Nova 1000, Quantachrome Corporation). SEM images were recorded with a Philips XL30 ESEM (Environmental Scanning Electron Microscope). The electrical conductivity measurements of the samples were performed using a KEITHLEY 6517A electrometer. The reflectance spectra of the samples were measured using a UV-VIS-NIR 3600 Shimadzu spectrophotometer with an integrating sphere attachment.

\section{Results and discussion}

\subsection{Structural properties of the $\mathrm{BaSn}_{0.99} \mathrm{Ge}_{0.01} \mathrm{O}_{3}$ ceramics}

Recently, Köferstein et al. [33] reported on the system $\mathrm{BaSnO}_{3}-\mathrm{BaGeO}_{3}$. They found a limited solid solubility of $\mathrm{BaGeO}_{3}$ in $\mathrm{BaSnO}_{3}$ of the order of $6-7 \mathrm{~mol} \%$, because of their different crystal structures. While $\mathrm{BaSnO}_{3}$ appears in the cubic perovskite structure, $\mathrm{BaGeO}_{3}$ crystallizes in two modifications having a pseudowollastonite-type structure and a pyroxene-type structure, respectively [35-37]. X-ray diffraction investigations of the calcined powder as well as the resulting sintered bodies show only the reflection pattern of $\mathrm{BaSnO}_{3}$ as demonstrated in Fig. 1. Therefore, the samples can be described as a solid solution between $\mathrm{BaGeO}_{3}$ and $\mathrm{BaSnO}_{3}$ written by the formula $\mathrm{BaSn}_{0.99} \mathrm{Ge}_{0.01} \mathrm{O}_{3}\left(\mathrm{Ge}^{\mathrm{IV}}\right.$ occupying the $\mathrm{Sn}^{I V}$ sites). $\mathrm{BaSn}_{0.99} \mathrm{Ge}_{0,01} \mathrm{O}_{3}$ ceramics reveal a drastically better sintering behavior than pure $\mathrm{BaSnO}_{3}$ ceramics [23]. An overview of the ceramic bodies is given in Table 1. Sintering at $1200{ }^{\circ} \mathrm{C}$ leads to ceramics with relative density of $82 \%\left(5.92 \mathrm{~g} / \mathrm{cm}^{3}\right)$. A relative density of $95 \%\left(6.83 \mathrm{~g} / \mathrm{cm}^{3}\right)$ is observed at a slightly higher temperature of $1250^{\circ} \mathrm{C}$. After sintering at 1300 and $1400^{\circ} \mathrm{C}$ we obtain ceramics with relative densities of 99\% [33].
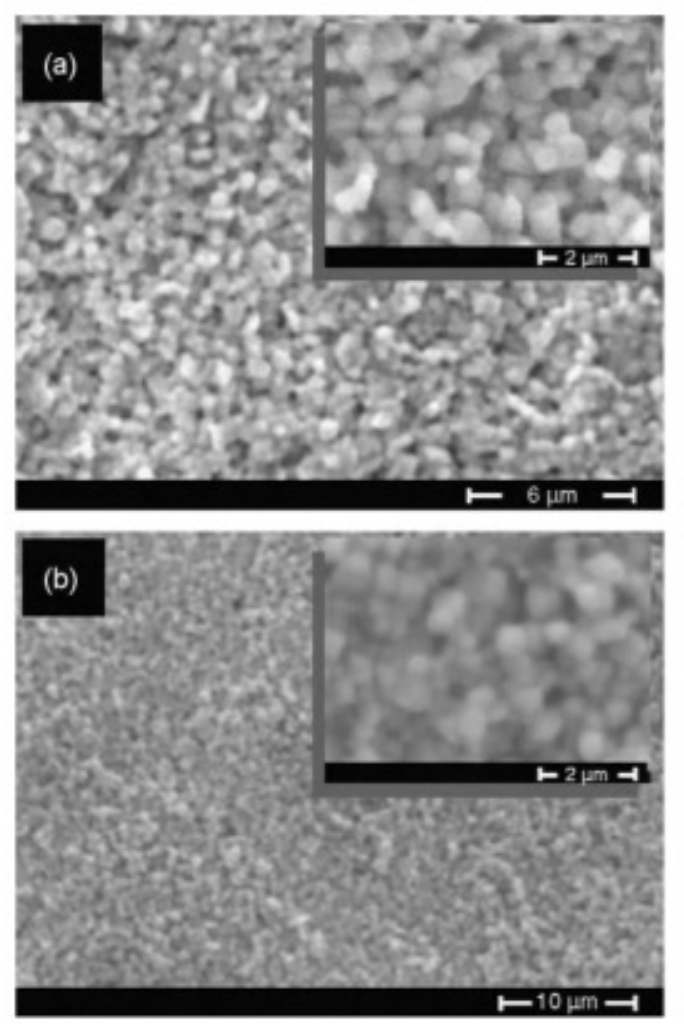

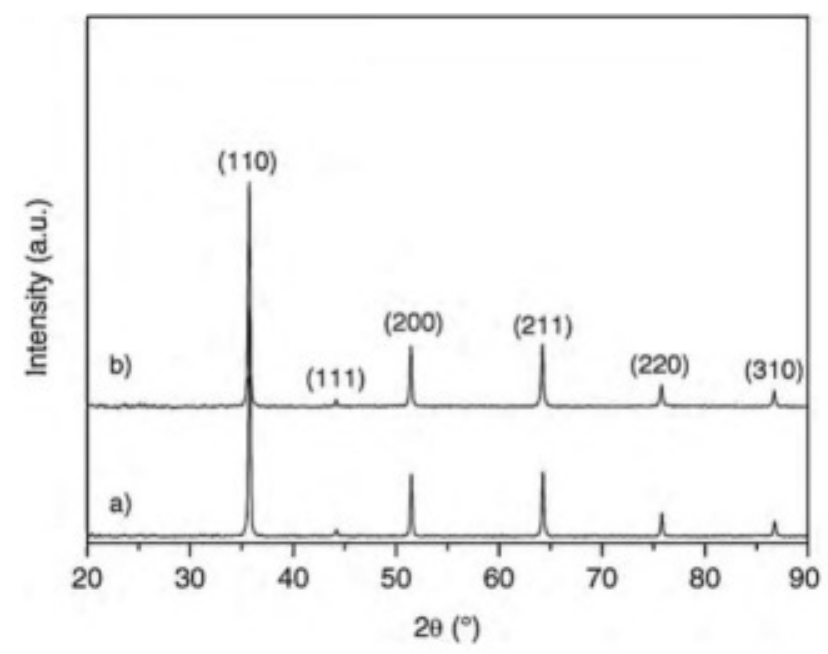

Fig. 1. XRD patterns of the calcined powder (a) and of a ceramic, sintered at $1400^{\circ} \mathrm{C}$ for $1 \mathrm{~h} \mathrm{(b).}$

Table 1

Structural parameters of the ceramics.

\begin{tabular}{llll}
\hline Sintering regime & $\begin{array}{l}\text { Relative } \\
\text { density }{ }^{\mathrm{a}}(\%)\end{array}$ & $\begin{array}{l}\text { Absolute density } \\
\left(\mathrm{g} / \mathrm{cm}^{3}\right)\end{array}$ & Grain size $(\mu \mathrm{m})$ \\
\hline $1400^{\circ} \mathrm{C}, 1 \mathrm{~h}$ & 99 & 7.18 & $2.5-26$ \\
$1300^{\circ} \mathrm{C}, 1 \mathrm{~h}$ & 99 & 7.13 & $2.5-7$ and $0.5-1$ (bimodal) \\
$1250^{\circ} \mathrm{C}, 1 \mathrm{~h}$ & 95 & 6.83 & $0.46-1.5$ \\
$1200^{\circ} \mathrm{C}, 1 \mathrm{~h}$ & 82 & 5.92 & $0.25-1$ \\
\hline
\end{tabular}

a Related to the theoretical density of $7.22 \mathrm{~g} / \mathrm{cm}^{3}$.

SEM images of the surface of the ceramic bodies are shown in Fig. 2. Ceramics sintered at $1200^{\circ} \mathrm{C}$ exhibit cubical-shaped grains between about 0.25 and $1 \mu \mathrm{m}$. Sintering at $1250^{\circ} \mathrm{C}$ leads only to a moderate grain growth between 0.45 and $1.5 \mu \mathrm{m}$. A further increasing sintering temperature to $1300^{\circ} \mathrm{C}$ causes a bimodal grain growth with grain fractions between about $0.5-1$ and $2.5-7 \mu \mathrm{m}$.
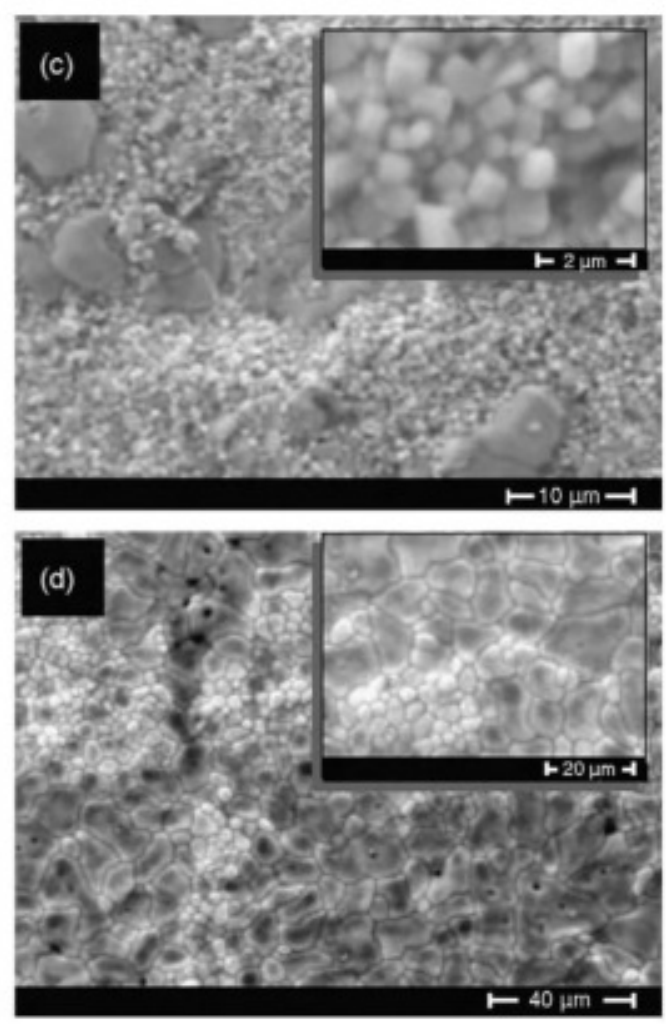

Fig. 2. SEM images of the ceramic bodies sintered at various temperatures for $1 \mathrm{~h}$. (a) $1200^{\circ} \mathrm{C}$, (b) $1250^{\circ} \mathrm{C}$, (c) $1300^{\circ} \mathrm{C}$, (d) $1400^{\circ} \mathrm{C}$. 


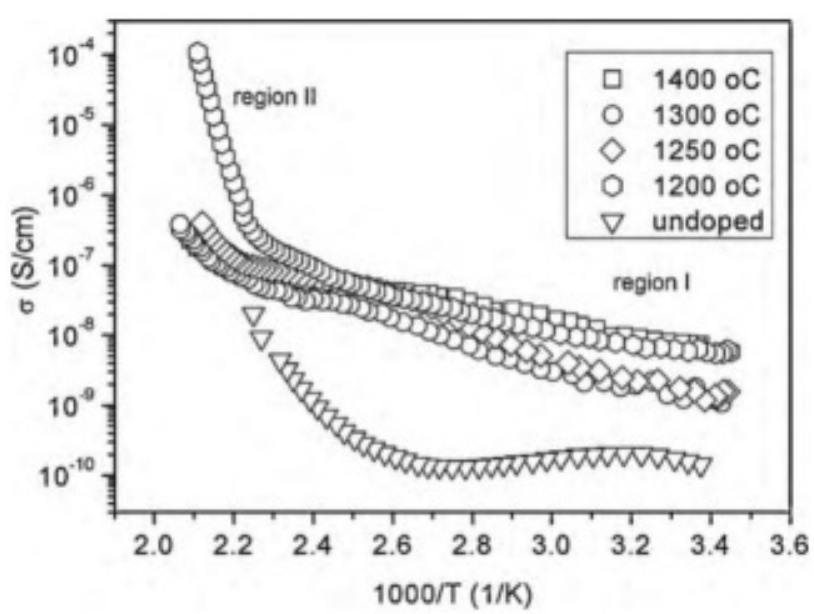

Fig. 3. Plots of electrical conductivity plots of the ceramics sintered at various temperatures.

The smaller grain fraction has cubical-shaped grains, whereas the larger grain fraction shows grains with a more irregular shape. At $1400{ }^{\circ} \mathrm{C}$ we obtain bodies with a heterogeneous grain distribution between 2.5 and $26 \mu \mathrm{m}$ (see also Ref. [33]).

\subsection{Electrical conductivity of the $\mathrm{BaSn}_{0.99} \mathrm{Ge}_{0.01} \mathrm{O}_{3}$ ceramics}

Fig. 3 shows electrical conductivity plots of undoped $\mathrm{BaSnO}_{3}$ and sintered $\mathrm{BaSn}_{0.99} \mathrm{Ge}_{0.01} \mathrm{O}_{3}$ ceramics. As seen in Fig. 3, the electrical conductivity of undoped $\mathrm{BaSnO}_{3}$ sample is lower than that of doped sample. This suggests that the electrical conductivity of undoped $\mathrm{BaSnO}_{3}$ increases with $\mathrm{Ge}$ dopant. The electrical conductivity of the samples increases with temperature, confirming that the samples exhibit the semiconductor behavior. The electrical conductivity plots show two linear regions (I and II) corresponding to various conduction mechanisms. The first region shows a linear at lower temperatures $\left(T<410^{\circ} \mathrm{C}\right)$ and second region followed a linear variation at higher temperature $\left(T>450^{\circ} \mathrm{C}\right)$. The electrical conductivity behavior of the ceramics were analyzed using the following relation:

$\sigma=\sigma_{\mathrm{o}} \exp \left(-\frac{\Delta E}{k T}\right)$

where $\sigma_{\mathrm{o}}$ is the pre-exponential factor, $E$ is the activation energy, $k$ is the Boltzmann constant. The activation energy values for I and II regions, $E_{1}$ and $E_{11}$, were determined from the slope of Fig. 3 and are given in Table 2 . The electrical conductivity values of ceramics at $25^{\circ} \mathrm{C}$ do not indicate a regular trend with sintering temperature. The ceramic sample sintered at $1200^{\circ} \mathrm{C}$ shows the highest conductivity. Comparing the electrical conductivity values of the samples with respect to sintering temperature, we evaluate that the grain size is an effective parameter in the conduction mechanism of the samples and the sample of the smallest grain size shows the highest conductivity. This shows that when the grain size was reduced to the nanometric regime, the electrical conductivity could be greatly enhanced.

The electrical conductivity of the samples sintered at 1400,1300 and $1250^{\circ} \mathrm{C}$ is lower than that of calcium modified $\mathrm{BaSnO}_{3}$, whereas

Table 2

Electrical parameters of the ceramics.

\begin{tabular}{lllll}
\hline Sint. temp. & $E_{\mathrm{g}}(\mathrm{eV})$ & $E_{\mathrm{l}}(\mathrm{eV})$ & $E_{1 \mathrm{l}}(\mathrm{eV})$ & $\sigma(\mathrm{S} / \mathrm{cm})$ \\
\hline $1400^{\circ} \mathrm{C}, 1 \mathrm{~h}$ & 2.95 & 0.223 & 0.518 & $4.54 \times 10^{-10}$ \\
$1300^{\circ} \mathrm{C}, 1 \mathrm{~h}$ & 3.03 & 0.356 & 0.889 & $1.08 \times 10^{-10}$ \\
$1250^{\circ} \mathrm{C}, 1 \mathrm{~h}$ & 3.07 & 0.415 & 1.280 & $1.10 \times 10^{-10}$ \\
$1200^{\circ} \mathrm{C}, 1 \mathrm{~h}$ & 3.1 & 0.264 & 3.177 & $6.31 \times 10^{-9}$ \\
\hline
\end{tabular}

the electrical conductivity of the sample sintered at $1200^{\circ} \mathrm{C}$ is higher than that of it [38]. The activation energy values of the samples for first (except for $1200^{\circ} \mathrm{C}$ ) and second regions decrease with increasing sintering temperatures. The samples sintered at 1250 and $1200^{\circ} \mathrm{C}$ have the higher activation energy values, 1.280 and $3.177 \mathrm{eV}$, respectively. This is attributed to long range diffusion of doubly ionized oxygen vacancies $V_{0} \cdot{ }^{*}$ in present perovskite oxides $[39,40]$. Whereas, the activation energy values of the samples sintered at 1300 and $1400^{\circ} \mathrm{C}$ is lower than that of the samples sintered at 1250 and $1200^{\circ} \mathrm{C}$, respectively. The long range diffusion of doubly ionized oxygen vacancies $V_{O}$ changes with increasing annealed temperatures.

\subsection{Optical properties of the $\mathrm{BaSn}_{0.99} \mathrm{Ge}_{0.01} \mathrm{O}_{3}$ ceramics}

Fig. 4a shows the reflectance spectra of the samples sintered at various temperatures. It is seen that the samples have high reflectance in the visible range of $400-700 \mathrm{~nm}$. The optical band gap of samples can be determined by the following relation [41]:

$\alpha h v=A\left(h v-E_{g}\right)^{n}$

where $\alpha$ is the absorption coefficient, $A$ is an energy-independent constant and $E_{\mathrm{g}}$ is the optical band gap. $n$ is a constant which determines the type of optical transitions and for indirect allowed transition, $n=2$ and indirect forbidden transition, $n=3$, for direct allowed transition, $n=1 / 2$; for direct forbidden transition, $n=3 / 2$. In order to determine optical band gaps of the samples, firstly. the reflectance values were converted to absorbance by application of the Kubelka-Munk function [42,43]. Kubelka-Munk theory is generally used for the analysis of diffuse reflectance spectra obtained from weakly absorbing samples. The optical band gap of lanthanum-doped stannate $\mathrm{BaSnO}_{3}$ has been determined using diffuse reflectance spectra [44]. Kubelka-Munk formula for determination of optical band gap of $\mathrm{BaSnO}_{3}$ ceramics is expressed by the following relation:

$F(R)=\frac{(1-R)^{2}}{2 R}$

where $R$ is the reflectance, $F(R)$ is the Kubelka-Munk function corresponding absorbance and $\alpha$ is determined using $\alpha=F(R) / d$, here $d$ is the thickness. The transmittance spectra of the ceramic sintered were obtained by means of Kubelka-Munk formula and are shown in Fig. 4b. The transmittance of the ceramic samples decreases with increasing sintering temperature. The sample sintered at $1250^{\circ} \mathrm{C}$ indicates the highest transparency. The transmittance of the samples changes with sintered temperature and indicates an absorption edge. The absorption edge varies with increasing sintering temperature, suggesting that the optical band gap changes with the temperature.

For determination of nature of the optical transitions, we have to find $n$ value. For this, Eq. (2) can be written in the following form [45]:

$\ln \alpha=\ln A-\ln (h v)+n \ln \left(h v-E_{\mathrm{g}}\right)$

In this equation, firstly, the approximate value of the optical band gap must be determined. When $E_{\mathrm{g}}$ is found, the value of $r$ can be determined from the slope of $\ln (h v)$ as a function of $\ln \left(h v-E_{\mathrm{g}}\right)$. If $(d(\ln \alpha) / d(h v))$ is plotted as a function of $(h v)$ for the compound, $d(\ln \alpha) / d(h v)=f(h v)$ will show a maximum value corresponding to approximate value of the optical band gap [46]. After determination of approximate value of the optical band gap, the value of $n$ is determined from the slope of $\ln (h v) v s . \ln \left(h v-E_{\mathrm{g}}\right)$ curve plotted and was found to be about 0.5 . This value suggests that the direct transitions are dominant in the samples and Eq. (2) can be therefore 

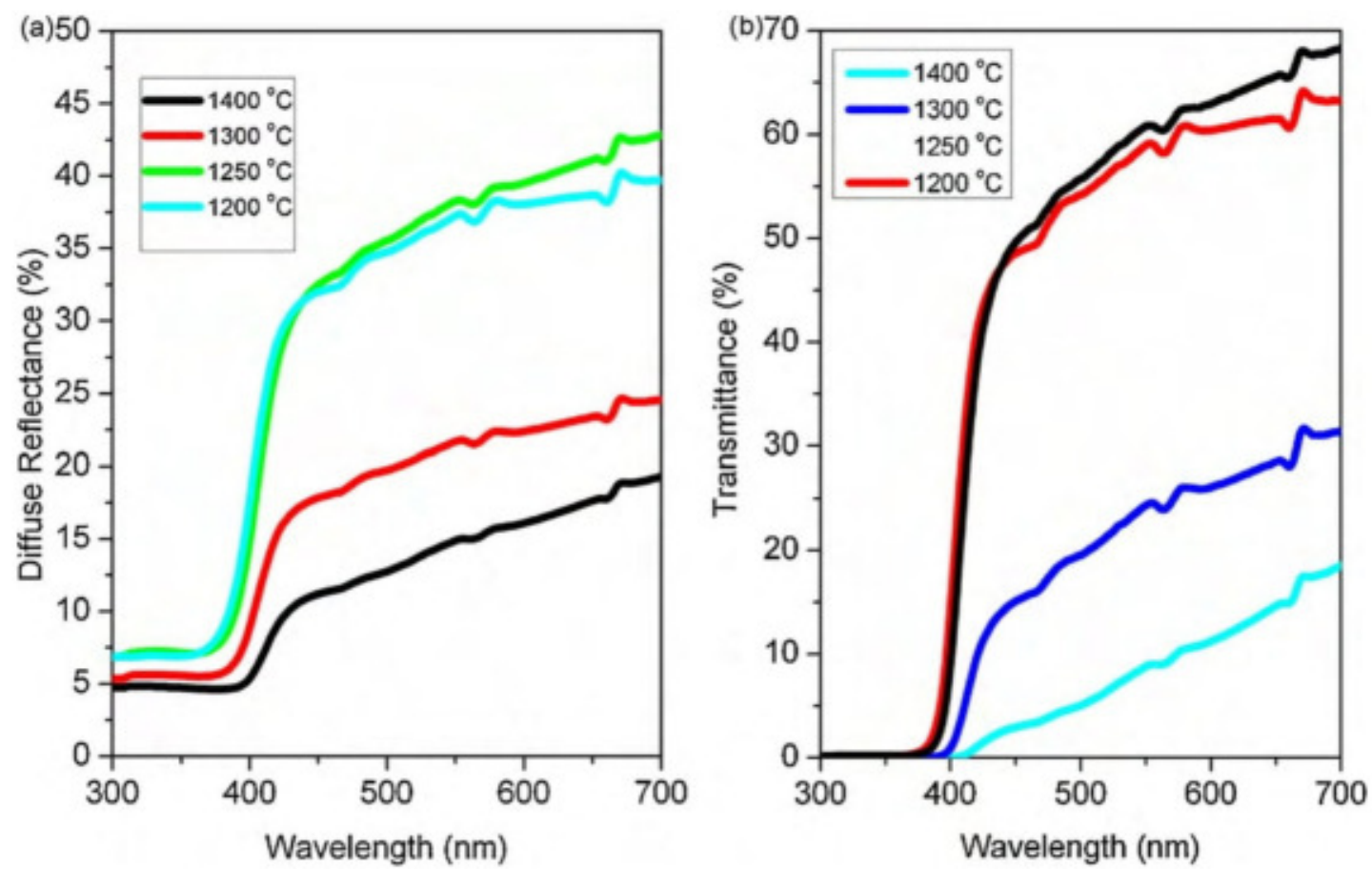

Fig. 4. Transmittance and reflectance spectra of the ceramics sintered at various temperatures.

written as follows:

$\alpha h v=A\left(h v-E_{g}\right)^{1 / 2}$

The exact optical band gap values of the samples was determined from the plots of $(\alpha h v)^{2}$ vs. $h v$, as shown in Fig. 5 and given in Table 2. It is evident from Table 2 that the value of $E_{\mathrm{g}}$ changes with sintering temperature. The obtained bad gap values of the samples are lower than that of $\mathrm{BaSnO}_{3}$, prepared by the mixedoxide method, which is a wide band gap material having an energy gap of $3.4 \mathrm{eV}[19,47]$. This suggests that the Ge dopant and sintering temperature decrease the optical band gap. The change in optical band gap with increasing annealing temperature could be attributed to the improved crystalline nature and porosity related

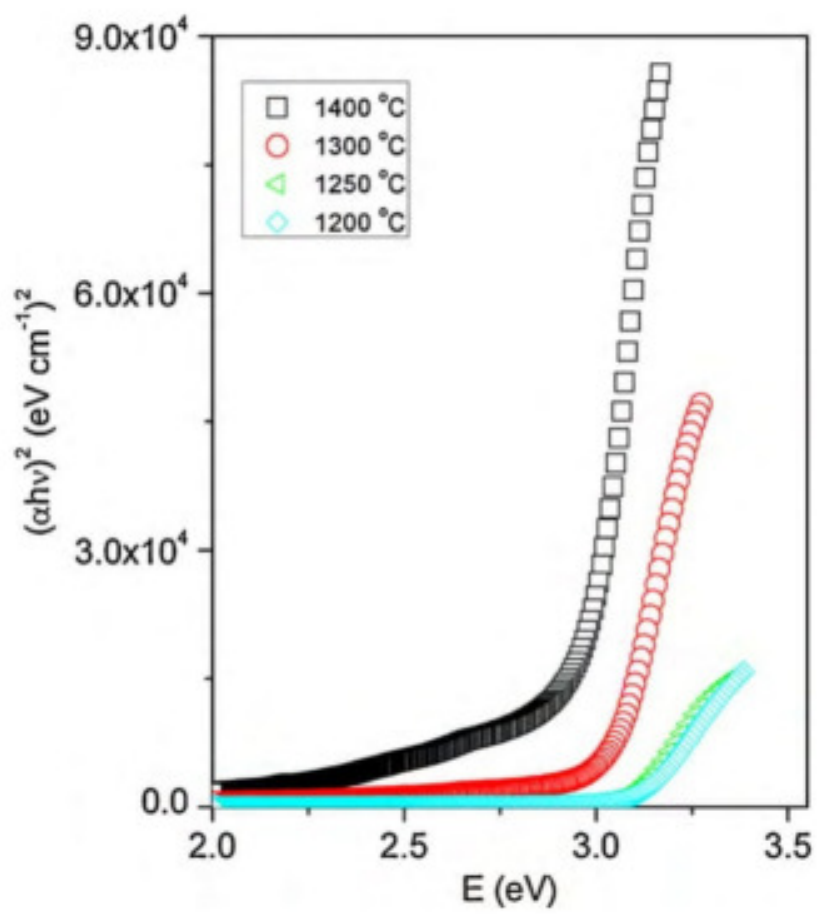

Fig. 5. Plots of $(\alpha h v)^{2}$ vs. hv of the ceramics sintered at various temperatures. to density change of films. The optical band gap of the samples is related to the crystalline nature, which in turn strongly depends on the annealing temperature and density. The $E_{\mathrm{g}}$ values of the samples are linearly decreased with the sintering temperature, as shown in Fig. 6 . The linearity change can be expressed [48]:

$E_{\mathrm{g}}(T)=E_{\mathrm{go}}+\beta T$

where $E_{\text {go }}$ is a constant and $\beta$ is the rate of change of band gap with temperature. The least-square fit of Fig. 6 gives:

$E_{\mathrm{g}}(T)=-7.6 \times 10^{-4} T\left({ }^{\circ} \mathrm{C}\right)+4.068$

From this relation, the $\beta$ value for the $\mathrm{BaSn}_{0.99} \mathrm{Ge}_{0.01} \mathrm{O}_{3}$ was found to be $7.6 \times 10^{-4}\left(\mathrm{eV} /{ }^{\circ} \mathrm{C}\right)$. We can evaluate that the decrease in the optical band gap of the $\mathrm{BaSn}_{0.99} \mathrm{Ge}_{0.01} \mathrm{O}_{3}$ is due to atomic distances changing by temperature. The sample sintered at $1400^{\circ} \mathrm{C}$ indicated a minimum optical band gap value of $2.95 \mathrm{eV}$. The optical band gap of the sample sintered at $1400^{\circ} \mathrm{C}$ is lower than that of lanthanumdoped $\mathrm{BaSnO}_{3}[44]$. It is evaluated that the sintering temperature has an important effect on the optical band gap of $\mathrm{BaSnO}_{3}$.

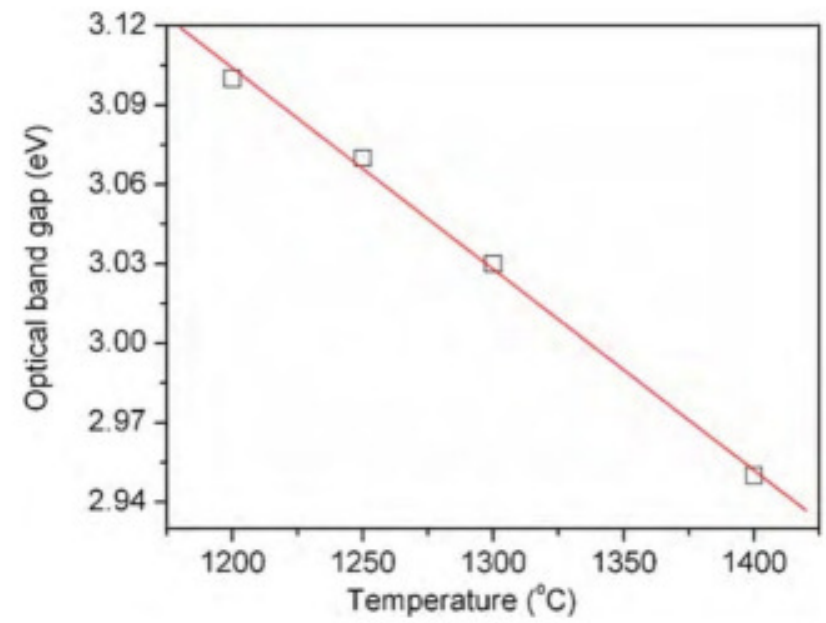

Fig. 6. Plots of $E_{\mathrm{z}}$ vs. $T$ of the ceramics sintered at various temperatures. 


\section{Conclusions}

The semiconducting properties of the Ge-doped $\mathrm{BaSnO}_{3}$ sintered at various temperatures have been investigated. The sintering temperature changed the electrical and optical properties of $\mathrm{Ge}-$ doped $\mathrm{BaSnO}_{3}$. The sample sintered at $1200^{\circ} \mathrm{C}$ shows the highest electrical conductivity, and also the sample sintered at $1400^{\circ} \mathrm{C}$ indicates the lowest band gap.

We have evaluated that $\mathrm{BaSn}_{0.99} \mathrm{Ge}_{0.01} \mathrm{O}_{3}$ is a wide band gap semiconductor with the determined electronic parameters.

\section{References}

[1] R. Vivekanandan, T.R.N. Kutty, Mater. Sci. Eng. B 6 (1990) 221.

[2] P.Singh, B.J. Brandenburg, C.P.Sebastian, P.Singh, S. Singh, D. Kumar, O. Parkash, K. Jpn. J. Appl. Phys. 47 (2008) 3540.

[3] A. Movchikova, O. Malyshkina, G. Suchaneck, G. Gerlach, R. Steinhausen, H.T. Langhammer, C. Pientschke, H. Beige, J. Electroceram. 20 (2008) 43.

[4] T. Wang, X.M. Chen, X.H. Zheng. J. Electroceram. 11 (2003) 173.

[5] A. Kumar, B.P.Singh, R.N.P. Choudhary. A.K. Thakur, Mater. Lett. 59 (2005) 1880.

[6] O.I. Prokopalo, Ferroelectrics 14 (1976) 683.

17] P. Singh, D. Kumar, O. Parkash, J. Appl. Phys. 97 (2005) 074103.

[8] H. Brauer, Z. Angew. Phys. 29 (1970) 282.

[9] B. Ostrick, M. Fleischer, U. Lampe, H. Meixner, Sens. Actuators B 44 (1997) 601.

[10] S. Tao, F. Gao, X. Liu, O.T. Sørensen, Sens. Actuators B 71 (2000) 223.

[11] S. Hodjati, K. Vaezzadeh, C. Petit, V. Pitchon, A. Kiennemann, Catal. Today 59 (2000) 323.

[12] P. McGeehin, D.E. Williams, Sensing Gaseous Substances. Int. Appl., Patent No. WO 9308467 A1 19930429, 1993.

[13] V.Gopal Reddy, S.V. Manorama, V.J. Rao, J. Mater. Sci. Mater. Electron. 12 (2001) 137.

[14] S. Upadhyay, P. Kavitha, Mater. Lett. 61 (2007) 1912.

[15] J. Cerda, J. Arbiol, G. Dezanneau, R. Diaz, J.R. Morante, Sens, Actuators B 84 (2002) 21.

[16] P.H. Borse, U.A. Joshi, S.M. Ji, J.S. Jang. J.S. Lee, E.D. Jeong, H.G. Kim, Appl. Phys. Lett. 90 (2007) 034103.

[17] Y. Yuan, J. Lv, X. Jiang. Z. Li, T. Yu, Z. Zou, J. Ye, Appl. Phys, Lett. 91 (2007) 094107.

[18] Y. Zhang. H. Zhang. Y. Wang. W.F. Zhang. J. Phys. Chem. C 112 (2008) 8553.
[19] J. Cava, P. Gammel, B. Batlogg.J.J. Krajewski, W.F. Peck Jr., W.L. RuppJr., R. Felder, R.B. van Dover, Phys. Rev. B 42 (1990) 4815.

[20] V.Jayaraman, G. Mangamma, T. Gnanasekaran, G. Periaswami, Solid State lonics $86-88$ (1996) 1111

[21] P.H. Borse, J.S. Lee, H.G. Kim, J. Appl. Phys. 100 (2006) 124915.

[22] A. Kumar, R.N.P. Choudhary. J. Mater. Sci. 42 (2007) 2476.

[23] R. Köferstein, L.Jäger, M. Zenkner, S.G. Ebbinghaus, J. Eur. Ceram. Soc. 29 (2009) 2317.

[24] P. Singh, D. Kumar, O. Parkash, J. Mater. Sci. Mater. Electron. 16 (2005) 145.

[25] X. Wie, X. Yao, Mater. Sci. Eng, B 137 (2007) 184.

[26] A.-M. Azad, N.C. Hon, J. Alloys Compd. 270 (1998) 95.

[27] B. Piercy. Trans. Faraday Soc. 55 (1959) 39.

[28] Z Wang, F. Zhou, Z. Chen, Dianzi Yuanjian Yu Cailiao 25 (2006) 58.

[29] R. Köferstein, L. Jäger, M. Zenkner, S.G. Ebbinghaus, Mater. Chem. Phys. 119 (2010) 118 .

[30] R. Köferstein, L Jäger, M. Zenkner, T. Müller, H.-P. Abicht, Mater. Chem. Phys. $112(2008) 531$.

[31] M. Zenkner, L. Jäger, R. Koferstein, H.-P. Abicht, Solid State Sci. 10 (2008) 1556

[32] R. Köferstein, L. Jäger, M. Zenkner, H.-P. Abicht, J. Mater. Sci. 43 (2008) 832.

[33] R. Köferstein, L. Jäger, M. Zenkner, T. Müller, S.G. Ebbinghaus, J. Eur. Ceram. Soc. $30(2010) 1419$

[34] G.W. Marks, L.A. Monson, Ind. Eng. Chem. 47 (1955) 1611.

[35] F. Liebau, Neues Jahrb. Miner. 94 (1960) 1209.

[36] W. Hilmar, Acta Crystallogr. 15 (1962) 1101.

[37] D.M. Tobbens, V. Kahlenberg. C. Gspan, G. Kothleitner, Acta Crystallogr. B62 (2006) 1002

[38] A. Kumara, B.P. Singh, R.N.P. Choudhary, A.K. Thakur, J. Alloys Compd. 394 (2005) 292.

[39] K.W. Browell, O. Mullar, R.H. Doreuies, Mater. Res, Bull. 11 (1976) 1475.

[40] A.E. Paladino, J. Am. Ceram. Soc. 48 (1965) 476.

[41] M.W. Charles, H. Nick Jr., E.S. Gregory, Physical Properties of Semiconductors, Prentice-Hall, Englewood Cliffs, NJ, 1989.

[42] F. Yakuphanoglu, R. Mehrotra, A. Gupta, M. Munoz, J. Appl. Polym. Sci. 114 (2009) 794.

[43] S.I. Boldish, W.B. White, Am. Miner. 83 (1998) 865

[44] B. Hadjarab, A. Bouguelia, M. Trari, J. Phys. D: Appl. Phys. 40 (2007) 5833.

[45] F. Yakuphanoglu, B.F. Senkal, A. Sarac, J. Electron. Mater. 37 (2008) 930.

[46] F. Yakuphanoglu, M. Arslan, Solid State Commun. 132 (2004) 229.

[47] G. Larramona, C. Gutierrez, I. Pereira, M. Rosa Nunes, F.M.A. da Costa, J. Chem. Soc. Faraday Trans. 85 (1989) 907.

[48] M.W. Charles, H. Nick Jr., E.S. Gregory, Optical Properties, Physical Properties of Semiconductors, Englewood Cliffs, New Jersey, 1989, pp. 218-219. 